Penanaman Nilai-nilai... Oleh: Yasin Nurfalah

\title{
PENANAMAN NILAI-NILAI PENDIDIKAN AGAMA ISLAM TERHADAP ANAK
}

\author{
Oleh: \\ Yasin Nurfalah \\ yesnurfalah@gmail.com \\ Institut Agama Islam Tribakti (IAIT) Kediri
}

\section{Abstrak}

Setiap anak mempunyai pembawaan berbeda dengan anak lain. Pembawaan itu merupakan cikal bakal dari karakteristik setiap individu. Pembawaan setiap anak juga akan tumbuh dan berkembang sesuai dengan lingkungan sosial mereka karena pada dasarnya manusia adalah makhluk sosial. Ini berarti, munculnya kenakalan pada anak dalam berbagai bentuk dan jenisnya bukan sematamata kesalahan mereka, tapi juga salah satu dampak negatif dari sebuah lingkungan yang kurang edukatif. Karena ada dasarnya setiap manusia dilahirkan dalam keadaan fitrah. Artinya, pertumbuhan dan perkembangan anak secara jasmani dan rohani adalah tanggung jawab semua pihak yang dimulai dari lingkungan keluarga, sekolah, dan masyarakat. Tanpa kesesuaian dan kerjasama antar ketiga komponen itu, maka anak akan menjadi rentan terpengaruh dan kemudian terbawa oleh perilakuperilaku yang dianggap menyimpang. Dalam konteks ini, sering kali yang menjadi sasaran kesalahan adalah anak, orang tua, dan dalam lingkup sekolah yang menjadi sasaran utama adalah mata pelajaran agama. Padahal, titik pijakan yang terpenting adalah bagaimana menanamkan nilai-nilai islami dalam diri anak sejak dini dan dilakukan oleh semua elemen secara kooperatif dan memberikan keteladanan dalam praktek kehidupan sehari-hari. Sehingga pengetahuan dan pemahaman akan nilai-nilai ajaran Islam dapat terwujud dalam bentuk perilaku.

Kata Kunci: Penanaman Nilai Keislaman, Anak. 
Penanaman Nilai-nilai... Oleh: Tasin Nurfalah

\section{Pendahuluan}

Lingkungan memainkan peran penting dalam membentuk kepribadian anak. Artinya, anak yang tumbuh dan berkembang di lingkungan yang baik, ia akan baik. Begitu pula sebaliknya dengan pembawaan mereka, bakat akan kurang berperan penting dalam membentuk pribadi anak jika berada dalam lingkungan yang tidak sesuai. ${ }^{1}$ Ini menujukkan bahwa pada dasarnya setiap anak mempunyai pembawaan berbeda dengan anak lain karena pembawaan itu merupakan cikal bakal dari karakteristik setiap individu. Selain itu, pembawaan setiap anak juga hanya akan tumbuh dan berkembang sesuai dengan lingkungan sosial mereka karena pada dasarnya manusia adalah makhluk sosial. Lingkungan sosial yang penuh dengan kejahatan akan menimbulkan kebiasaan-kebiasaan yang buruk bagi anak. Sedangkan lingkungan yang baik, latihan-latihan yang baik akan membantu memperbaiki tingkah laku seseorang menjadi pribadi yang baik.

Perkembangan arus globalisasi saat ini semakin cepat dan dampaknya tidak selalu positif. Berbagai macam kemajuan atau kecanggihan teknologi dan kecepatan informasi digital juga dapat menjadi salah satu faktor yang mendorong perilaku menyimpang, termasuk bagi anak-anak dan remaja. Dalam konteks ini, kenakalan remaja merupakan salah satu keniscayaan yang tidak dapat dipungkiri selalu muncul dalam beragam bentuk, waktu, dan tempat berbeda. Tapi, kenakalan tersebut juga bukan sepenuhnya merupakan kesalahan anak-anak atau remaja. Hal ini sejalan dengan pendapat Risma saat melakukan penyuluhan di SMPN 8, bahwa kenakalan siswa saat ini bukan sepenuhnya kesalahan anak, tapi semua bersalah termasuk saya, orang tua, siswa, dan lingkungan. ${ }^{2}$

Adapun bentuk kenakalan remaja menurut Anwar Sutoyo dalam Achmad Farid di antaranya: suka berkelahi, suka

1 Syaiful Bahri Djamarah, Guru dan Anak Didik dalam Interaksi Edukatif: Suatu Pendekatan Teoretis Psikologis (Jakarta: Rineka Cipta, 2005), h. 53.

2 Zaenal Effendi, "Begini Cara Risma Cegah Kenakalan Remaja di Sekolah", detik news 15 Februari 2018 dalam https://news.detik.com/beritajawa-timur/d-3868490, diakses 17 April 2018. 
geng motor, mengubah ciptaan tuhan (bertato, semiran), kecanduan alkohol dan sejenisnya serta berbagai bentuk maksiat lainnya. ${ }^{3}$ Perilaku-perilaku menyimpang itu perlu diminimalisir dengan melibatkan berbagai pihak yang dimulai sejak dini dari lingkungan keluarga, sekolah, dan masyarakat secara terpadu dan berkelanjutan dengan menggunakan pendekatan atau sentuhan rohani secara perlahan karena sesungguhnya setiap manusia dilahirkan dalam keadaan fitrah. Tanpa upaya yang serius dan niat yang tulus yang semata-mata untuk mencari ridla Allah, maka pada saat tertentu usaha itu akan mengalami titik jenuh dan tidak membuahkan hasil seperti yang diharapkan.

Jika dikaitkan dengan nilai-nilai agama Islam, kondisi remaja saat ini dapat terbilang jauh dari harapan dan cukup memprihatinkan. Tentu hal ini tidak harus terjadi, khususnya pada anak yang masih di bawah umur. Problem tersebut merupakan salah satu bagian dari krisis multidimensional yang berpangkal dari krisis akhlak atau moral. Krisis ini, baik secara langsung ataupun tidak langsung sangat berkaitan dengan persoalan pendidikan. Bagi sebagian pihak, problem tersebut merupakan wujud dari kegagalan pendidikan agama. Padahal, tugas untuk mendidik akhlak mulia bukan hanya tugas guru pendidikan agama semata, tapi juga tugas semua guru dan dosen untuk mengimplisitkan nilai-nilai ajaran Islam dalam setiap bidang studi yang dipelajari oleh dan diajarkan pada anak didik. ${ }^{4}$

Hal ini berarti bahwa, pengetahuan dan pemahaman mengenai ajaran Islam harus diajarkan kepada anak sejak dini sebagai bekal dalam kehidupan mereka. Dengan berbekal pengetahuan ajaran Islam, maka seiring dengan bertambahnya usia anak, ia akan tahu bagaimana harus bersikap terhadap tuhan, sesama, dan terhadap lingkungannya. Anak akan bertindak sesuai dengan aturan-aturan Islam ketika berada di masyarakat. Hasilnya anak akan diterima oleh masyarakat

${ }^{3}$ Achmad Farid, "Model Bimbingan Konseling Islam Anwar Sutoyo dalam Mengatasi Kenakalan Remaja", Konseling Religi: Jurnal Bimbingan Konseling Islam, Vol. 6, No. 2, Desember 2015, h. 381-400.

${ }^{4}$ Muhaimin, Pengembangan Kurikulum Pendidikan Agama Islam di Sekolah, Madrasah, dan Perguruan Tinggi (Jakarta: Rajawali Pers, 2010), h. 18-19. 
sekitarnya dalam hal bersosialisasi. Melalui pembekalan pengetahuan kepada anak didik tentang berbuat sesuai dengan ajaran Islam, anak dapat belajar berperilaku dengan cara yang diterima masyarakat, dan sebagai hasilnya diterima sebagai anak yang baik/shaleh oleh anggota kelompok sosial mereka. Penanaman nilai-nilai islami pada anak didik sangat penting dan perlu diinternalisasikan sejak dini agar mereka nantinya terbiasa berbuat hal-hal yang sesuai dengan ajaran agama Islam. Selanjutnya, dalam tulisan ini penulis akan memfokuskan pada hal-hal yang berkenaan dengan penanaman nilai-nilai ajaran Islam dalam membentuk dan mengarahkan kepribadian anak dari segi pemahaman, sikap, dan perilaku yang sesuai dengan ajaran Islam.

\section{Pembahasan}

\section{Konsep Pendidikan Agama Islam}

Pendidikan agama mempunyai beberapa definisi. Dalam tulisan ini, definisi yang digunakan adalah definisi resmi sebagaimana diungkapkan dalam Peraturan Menteri Agama (permenag) nomor 16 tahun 2010 bahwa, pendidikan agama adalah pendidikan yang memberikan pengetahuan dan membentuk sikap, kepribadian, dan keterampilan peserta didik dalam mengamalkan ajaran agamanya, yang dilaksanakan sekurang-kurangnya melalui mata pelajaran pada semua jalur, jenjang, dan jenis pendidikan. Tujuannya adalah untuk menjamin terselenggaranya pendidikan agama yang bermutu di sekolah. Pendidikan agama terdiri dari dari pendidikan agama Islam, Katolik, Kristen, Hindu Buddha, dan pendidikan agama Khonghucu. Penyelenggaraan pendidikan agama bersifat wajib bagi setiap sekolah. ${ }^{5}$

Definisi di atas menunjukkan bahwa pada dasarnya semua agama mengajarkan kebaikan pada semua individu untuk menjadi pribadi sejati. Hal itu dapat terwujud melalui pemahaman keagamaan yang utuh dan sesuai dengan semangat dan falsafah bangsa Indonesia, kemudian termanifestasikan

${ }^{5}$ Peraturan Menteri Agama No. 16 tahun 2010 tentang Pengelolaan Pendidikan Agama pada Sekolah, h. 3-4. 
dalam sikap, kepribadian dan keterampilan berdasarkan ajaran agamanya masing-masing. Dalam tulisan ini, pendidikan agama yang dimaksud adalah pendidikan agama Islam. Berarti sumber sepenuhnya mengacu pada sumber-sumber agama Islam.

Menurut Zuhairini dkk, pendidikan Islam adalah usaha yang diarahkan pada pembentukan pribadi anak yang sesuai dengan ajaran Islam baik dari cara berpikir, berbuat, dan bertanggung jawab sesuai dengan ajaran dan nilai-nilai islam. Sejalan dengan definisi tersebut, Zuhairini juga membuat klasifikasi atau urutan prioritas pendidikan Islam dalam membentuk kepribadian muslim yang dimulai dari pendidikan keimanan kepada Allah sebagai landasan sikap, perilaku, dan kepriadian anak didik. Selanjutnya adalah pendidikan akhlak mulia sebagai modal bagi setiap orang dalam menghadapi pergaulan antar sesama. Setelah itu, pendidikan ibadah dalam makna luas yang tidak hanya dimaknai sebagai penyembahan, melainkan juga berhubungan dengan laku manusia meliputi kehidupan material dan spiritual sebagaimana kesatuan jiwa dan badan. $^{6}$

Dalam hal ini, Muhaimin juga menjelaskan bahwa pendidikan agama Islam adalah usaha sadar untuk menyiapkan peserta didik dalam meyakini, memahami, menghayati, dan mengamalkan agama Islam melalui kegiatan bimbingan, pengajaran, dan/atau latihan dengan memperhatikan tuntutan untuk menghormati agama lain dalam kerukunan antar umat beragama dalam masyarakat untuk mewujudkan persatuan nasional. ${ }^{7}$ Secara singkat pendidikan agama Islam dapat diartikan sebagai upaya mendidikkan agama Islam atau ajaran Islam beserta nilai-nilainya agar menjadi pandangan dan sikap hidup (way of life). ${ }^{8}$

a. Dasar Pendidikan Agama Islam

${ }^{6}$ Zuhairini, Filsafat Pendidikan Islam (Jakarta: PT. Bumi Aksara, 2008), h. 152-158.

7 Muhaimin, et. al, Paradigma Pendidikan Islam: Upaya Mengefektifkan Pendidikan Agama Islam di Sekolah, Madrasah, dan Perguruan Tinggi (Jakarta: PT. RajaGrafindo Persada, 2010), h. 85.

${ }^{8}$ Muhaimin, Pengembangan Kurikulum, h. 7-8. 
Dasar pendidikan agama Islam mengacu pada dasar agama Islam yaitu al-Quran dan al-Hadits. Dasar tersebut kemudian dikembangkan dalam pemahaman para ulama dalam bentuk ijtihad yang meliputi qiyas dan ijma' yang diakui. ${ }^{9}$ Sebagai sumber agama Islam, al-Quran menempati posisi sentral, bukan hanya dalam perkembangan dan pengembangan ilmu-ilmu keislaman, tapi juga sebagai kerangka segala kegiatan. ${ }^{10}$ Di samping itu, al-Quran juga bersifat fungsional, yaitu menyangkut berbagai aspek kehidupan manusia, maka nilai-nilai ajarannya berfungsi untuk manusia kapan dan di manapun berada. Di dalam alQuran terdapat banyak ajaran yang memuat prinsip pendidikan, misalnya kisah Lukman yang terabadikan dalam surat al-Lukman, dan sebagainya. ${ }^{11}$

Sumber kedua agama dan ajaran Islam adalah al-Hadits yang sekaligus menjadi penafsir pertama dan bagian kompelementer al-Quran. ${ }^{12}$ Salah satu Hadits yang dapat dijadikan dasar pendidikan agama tercermin dalam sebuah Hadits dalam kitab Ihya' Ulumuddin sebagaimana dikutip Zuhairini yang artinya: ${ }^{13}$

"Sesungguhnya orang mukmin yang paling dicintai Allah ialah orang yang senantiasa taat kepada-Nya dan memberikan nasihat pada hamba-Nya, sempurna akal pikirannya serta menasihati pula akan dirinya sendiri, menaruh perhatian serta mengamalkan ajaran-Nya selama hayatnya, maka beruntung dan memperoleh kemenangan ia".

b. Tujuan Pendidikan Agama Islam

Tanpa tujuan, kegiatan yang telah dan akan dilakukan akan kurang bermakna karena tujuan dapat memberikan arah

9 Muhammad Azmi, Pembinaan Akhlak Anak Usia Pra-Sekolah: Upaya Mengefektifkan Nilai-nilai Pendidikan Islam dalam Keluarga (Yogyakarta: Belukar, 2006), h. 24.

10 Mohammad Daud Ali, Pendidikan Agama Islam (Jakarta: PT. RajaGrafindo Persada, 2010), h. 106.

${ }^{11}$ Azmi, Pembinaan Akhlak, h. 25-26.

12 Ali, Pendidikan Agama, h. 115.

${ }^{13}$ Zuhairini, Filsafat Pendidikan, h. 153. 
yang jelas dan menempati posisi penting dalam semua aktifitas. $^{14}$ Menurut Al-Aynany dalam Azmi, tujuan pendidikan Islam secara umum terbagi dua, yaitu tujuan umum dan tujuan khusus. Tujuan umum yaitu untuk beribadah kepada Allah. Tujuan ini sifatnya tetap berlaku di semua tempat, waktu, dan keadaan. Sedangkan tujuan khusus ditetapkan berdasarkan keadaan tempat dan mempertimbangkan kondisi geografis tempat tersebut. Tujuan ini dapat dirumuskan berdasarkan ijtihad para ahli sesuai tempat masing-masing. ${ }^{15}$

Selain itu, Mohammad Athiyah Al-Abrosyi dalam Zuhairini menyimpulkan lima tujuan asasi pendidikan Islam, antara lain: membantu perkembangan akhlak mulia, persiapan kehidupan dunia dan akhirat, menumbuhkan spirit ilmiah, persiapan professional dan teknis, dan sebagai persiapan untuk mencari rezeki dan pemeliharaan segi-segi kemanfaatan. Kelima tujuan itu berfungsi dan bermakna untuk membentuk kepribadian muslim yang mencakup perpaduan iman dan amal saleh. ${ }^{16}$

Adapun tujuan diberikannya pendidikan agama Islam di sekolah dalam bentuk mata pelajaran yang diberikan bertujuan untuk: ${ }^{17}$

1. Meningkatkan keimanan dan ketakwaan pada Allah SWT dalam diri peserta didik melalui pengenalan, pemahaman, penghayatan terhadap ayat-ayat Allah yang tercipta dan tertulis (ayat kauniyyah dan ayat qauliyyah),

2. Membentuk karakter muslim dalam diri peserta didik melalui pengenalan, pemahaman, dan pembiasaan norma-norma dan aturan-aturan Islam dalam melakukan relasi yang harmonis dengan Tuhan, diri sendiri, sesama, dan lingkungannya; dan

${ }^{14}$ Djamarah, Guru dan Anak Didik, h. 27.

${ }^{15}$ Azmi, Pembinaan Akhlak, h. 30.

${ }^{16}$ Zuhairini, Filsafat Pendidikan, h. 164-166.

${ }^{17}$ Keputusan Menteri Agama Republik Indonesia Nomor 211 tahun 2011 tentang Pedoman Pengembangan Standar Nasional Pendidikan Agama Islam pada Sekolah 
3. Mengembangkan nalar dan sikap moral yang selaras dengan keyakinan Islam dalam kehidupan sebagai warga masyarakat, warga negara, dan warga dunia.

c. Materi Pendidikan Agama Islam

Materi pendidikan agama Islam mengacu pada dasar pendidikan agama Islam yaitu al-Quran dan al-Hadits. Mengikuti kedua dasar tersebut, maka kerangka dasar materi pendidikan agama Islam terdiri dari akidah, syari'ah, dan akhlak. ${ }^{18}$ Berikut ini penjelasan masing-masing komponen tersebut: ${ }^{19}$

1. Akidah yaitu penekanan pada kemampuan memahami dan mempertahankan keyakinan, serta menghayati dan mengamalkan nilai-nilai asma'ul husna sesuai dengan kemampuan peserta didik. Pengertian teknis akidah adalah iman atau keyakinan. Karenanya akidah sangat berkaitan erat dengan rukun iman sebagai asas seluruh ajaran Islam dan merupakan pegangan hidup. ${ }^{20}$

2. Syariah yaitu penekanan pada cara melakukan ibadah dan mu'amalah yang baik dan benar. Secara harfiah, syari'ah berarti jalan yang harus dilalui setiap muslim (the way of life). ${ }^{2}$

3. Akhlak menekankan pada pengamalan sikap terpuji dan menghindari perbuatan-perbutan tercela. Arti harfiah akhlak adalah budi pekerti atau kelakuan yang merupakan sikap hidup muslim. ${ }^{22}$ Dalam al-Quran, kata akhlak merujuk pada bentuk tunggal, yaitu khuluq sebagaimana tercantum dalam surat al-Qalam ayat 4 . Ayat tersebut dinilai sebagai konsiderans pengangkatan Nabi Muhammad SAW sebagai Rasul: ${ }^{23}$

${ }_{18}$ Ali, Pendidikan Agama, h. 133.

19 Keputusan Menteri Agama Republik Indonesia Nomor 211 tahun 2011 tentang Pedoman Pengembangan Standar Nasional Pendidikan Agama Islam pada Sekolah

${ }^{20}$ Ali, Pendidikan Agama, h. 199.

${ }^{21}$ Ibid., h. 235.

${ }^{22}$ Ibid., h. 346.

23 Quraish Shihab, Wawasan Al-Quran: Tafsir Maudhu'i atas Pelbagai Persoalan Umat (Bandung: Penerbit Mizan, 1996), h. 252. 


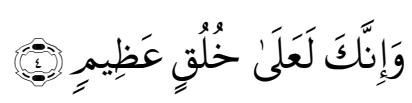

Terjemahnya: Dan Sesungguhnya engkau (Muhammad) berada di atas budi pekerti yang agung (QS. al-Qalam: 4).

Ketiga komponen tersebut merupakan penggolongan yang mengacu pada arti iman, Islam, dan ihsan. Kemudian ketiga komponen itu juga terus berkembang hingga akhirnya membentuk ilmu-ilmu keislaman yang mandiri yaitu ilmu tauhid, ilmu fikih, dan ilmu akhlak.

\section{Penanaman Nilai-nilai Pendidikan Agama Islam pada Anak}

Penanaman nilai sangat identik dengan akhlak. Konsep lain yang setara namun berbeda dengan akhlak adalah etika dan moral. Etika berasal dari bahasa Yunani yaitu ethos yang artinya adat, watak atau kesusilaan. Sedangkan moral berasal dari bahasa Latin yaitu mos, artinya adat atau cara hidup. Kedua istilah tersebut sama-sama menentukan nilai baik dan buruk dari sikap atau perbuatan. Perbedaannya terletak pada sumbernya. Akhlak bersumber pada al-Quran, etika bersumber pada pertimbangan rasio, dan moral bersumber pada adat kebiasaan yang berlaku dalam suatu masyarakat. Akhlak dapat dipahami sebagai sifat yang tertanam dalam jiwa manusia sehingga akan muncul secara spontan saat diperlukan tanpa memerlukan pemikiran atau pertimbangan terlebih dahulu. ${ }^{24}$

Misalnya dalam suatu organisasi atau dunia kerja, jika seorang pimpinan bersikap pemilih dalam memberikan kebijakan atau dispensasi yang tidak berdasarkan aturan, melainkan justru berdasarkan kepentingan atau alasan pribadi, jenis kelamin, suku, agama, golongan, dan sebagainya. Maka pemimpin tersebut belum bisa dikatakan mempunyai sifat adil. Sebab, seorang pimpinan yang mempunyai akhlak adil tidak akan bersikap demikian tanpa mempertimbangkan aturan, prosedur, dan konteks yang menjadi latar belakang diputuskannya suatu kebijakan atau dispensasi.

${ }^{24}$ Azmi, Pembinaan Akhlak, h. 55-56.

Volume 29 Nomor 1 Januari-Juni 2018 
Dengan demikian, penanaman nilai yang dimaksud dalam tulisan ini adalah nilai yang diturunkan dari aspek-aspek pendidikan agama Islam, antara lain nilai keimanan, ibadah, dan akhlak. Ketiga nilai tersebut dihubungkan dengan cakupan pendidikan agama Islam yang meliputi keserasaian, keselarasan, dan keseimbangan antara hubungan manusia dengan Allah, diri sendiri, sesama manusia, dan alam sekitar atau lingkungan. Hubungan-hubungan itu termanifestasikan dalam bentuk sikap dan perilaku yang seharusnya dilakukan manusia, berikut ini penjelasan masing-masing hubungan tersebut: ${ }^{25}$

a. Sikap dan perilaku terhadap Allah

Hal pertama yang harus ditanamkan kepada anak dalam bersikap dan berperilaku kepada Allah adalah mentauhidkan Allah, yaitu pengakuan dan kesadaran bahwa tidak ada tuhan melainkan Allah. Keyakinan atas keesaan Allah seperti bahwa perbuatan Allah tidak sama dengan perbuatan manusia, meskipun penamaannya sama.

Misalnya, allah mempunyai sifat maha pengasih dan penyayang, manusia juga mempunyai kedua sifat itu. Tapi, hakikat dan kapasitas rahmat dan kemurahan Allah tidak dapat disamakan dengan apa yang dimiliki manusia karena mempersamakan hal itu sama dengan menggugurkan keesaan Allah.

Bentuk sikap dan perilaku lain harus ditanamkan antara lain: mencintai Allah melebihi cinta kepada yang lain, melaksanakan perintah dan menjauhi larangan, mengharap dan berusaha mencapai ridla Allah, mensyukuri segala pemberian dan karunia Allah, bersabar dan ikhlas menerima cobaan, bertaubah hanya kepada Allah, dan bertawakkal kepada Allah.

b. Sikap dan perilaku terhadap sesama manusia

Dasar dari sikap dan perilaku sesama manusia adalah sikap dan perilaku terhadap hati nurani dan diri sendiri. Hal ini banyak dijelaskan dalam ayat-ayat takwa dan keteladanan Rasulullah SAW, antara lain senantiasa berlaku sabar, pemaaf, adil, ikhlas, berani, amanah dan mengembangkan

${ }^{25}$ Azmi, Pembinaan Akhlak, h. 63-78. 
semua akhlak yang baik dan meminimalisasi berbagai penyakit hati. Selanjutnya, sikap dan perilaku tersebut teraktualisasikan dalam hubungan antar sesama manusia. Hubungan sesama manusia dapat dibina dan dipelihara dengan sikap saling tolong menolong, saling memaafkan, menepati janji, lapang dada, menegakkan keadilan baik bagi diri sendiri maupun bagi orang lain. ${ }^{26}$

Secara khusus sikap dan perilaku antar sesama manusia dapat dikelompokkan dalam beberapa bagian. Pertama, kepada Rasulullah, sikap dan perilaku kepada rasulullah diwujudkan dalam bentuk melaksanakan segala perintah dan menjauhi larangannya, mengikuti sunnah-sunnahnya, menjadikan Rasulullah sebagai idola dan teladan kehidupan. Kedua, kepada orang tua. Bentuknya berupa sikap dan perilaku menghormati, menaati, dan berbuat baik dan lemah lembut. Ketiga, kepada keluarga. Diwujudkan dalam bentuk saling membina rasa kasih sayang, menunaikan hak dan kewajiban, dan memelihara silaturahmi. Keempat, kepada tetangga. Diwujudkan dalam bentuk saling mengunjungi, membantu, memberi, menghormati, dan menghindari pertengkaran. Kelima, kepada masyarakat. Bentuknya berupa memuliakan tamu, menghormati nilai dan norma yang berlaku, saling tolong menolong dan mengingatkan dalam kebaikan dan mencegah perbuatan buruk. ${ }^{27}$

c. Sikap dan perilaku terhadap alam atau lingkungan

Hormat kepada alam merupakan suatu prinsip dasar bagi manusia sebagai bagian dari alam semesta secara seluruhnya. $^{28}$ Hubungan manusia dengan alam atau lingkungan sekitar dapat dikembangkan dengan cara memelihara dan menyayangi binatang, tumbuhan, dan semua hal yang Allah ciptakan di dunia ini. Selain itu, dengan cara mencegah perusakannya. ${ }^{29}$ Islam memandang alam sebagai milik Allah yang wajib disyukuri dengan menggunakan dan

${ }^{26}$ Ali, Pendidikan Agama Islam, h. 369-370.

${ }^{27}$ Azmi, Pembinaan Akhlak, h. 64-77.

28 A. Sonny Keraf, Etika Lingkungan Hidup (Jakarta: Penerbit Buku Kompas, 2010), h. 167.

${ }^{29}$ Ali, Pendidikan Agama Islam, h. 371. 
mengelola alam sebaik-baiknya, agar dapat memberi manfaat bagi kehidupan manusia. Untuk itu, sikap dan perilaku kepada alam perlu ditanamkan kepada anak sedini mungkin, agar mereka dapat memilihara dan menjaga keseimbangan alam, serta memelihara kebersihan dan keindahan lingkungan, sehingga tetap nyaman dan indah sebagai wujud ketaatan kepada Allah.

Nilai-nilai tersebut dapat ditanamkan pada anak sejak kecil agar mereka memahami nilai-nilai islami secara konkret dan terbiasa untuk mempraktekkannya dalam kehidupan seharihari. Penanaman nilai-nilai tersebut harus dilaksanakan oleh semua pihak, di antaranya: orang tua, guru, dan masyarakat. Pelaksanaannya dapat mengacu pada prinsip-prinsip pendidikan nilai, yaitu: prinsip keteladanan, membimbing, membantu, dan pengembangan nilai dan prinsip pembuatan keputusan. ${ }^{30}$

Penjelasan di atas memberikan pemahaman bahwa, penanaman nilai-nilai pendidikan agama Islam bagi anak harus dimulai sejak dini oleh semua pihak dan tidak cukup hanya mengandalkan pengajaran di sekolah atau, melainkan harus melibatkan partisipasi dan dorongan semua pihak yang mengacu pada prinsip-prinsip yang ada, khususnya melalui bimbingan untuk selalu mengajarkan dan mengarahkan, memberikan pembiasaan dan keteladanan. Hal ini dilakukan agar anak tidak hanya mengembangkan dimensi kognitifnya, tapi mengupayakan semua dimensi dan potensinya berkembang secara optimal dan terintegrasi secara baik berdasarkan konteks kehidupan kebangsaan dan keagamaan mereka.

Dengan demikian, betapapun deras dan cepatnya arus globalisasi, anak-anak tidak akan mudah terperangkap ke dalam dampak negatif yang pada akhirnya membuat mereka kehilangan jati diri dan makna nilai-nilai kebangsaan maupun keislamannya. Justru mereka akan menjadi embrio generasi masa depan yang lebih baik karena mampu menyikapi dan memadukan berbagai perkembangan ilmu pengetahuan dan teknologi dengan agama.

30 Maksudin, Pendidikan Nilai Komprehensif: Teori dan Praktik (Yogyakarta: UNY Press, 2009), h.114. 


\section{Penutup}

Pada bagian ini, penulis ingin menegaskan kembali bahwa penanaman nilai-nilai ajaran Islam pada anak harus dimulai sejak mereka kecil. Selain itu, dalam proses itu juga harus melibatkan partisipasi semua pihak yang dimulai dari lingkungan keluarga, sekolah, dan masyarakat sekitar karena sejatinya penanaman nilai-nilai dalam diri anak adalah tanggung jawab semua pihak. Adapun komponen materi keilmuan yang harus ditanamkan adalah tauhid, ilmu fikih, dan ilmu akhlak. Kemudian Ketiga nilai tersebut dihubungkan dengan ruang lingkup pendidikan agama Islam yang meliputi keserasaian, keselarasan, dan keseimbangan antara hubungan manusia dengan Allah, diri sendiri, sesama manusia, dan alam sekitar atau lingkungan. 
Penanaman Nilai-nilai... Oleh: Tasin Nurfalah

\section{DAFTAR PUSTAKA}

Ali, Mohammad Daud. Pendidikan Agama Islam. Jakarta: PT. RajaGrafindo Persada, 2010.

Azmi, Muhammad. Pembinaan Akhlak Anak Usia Pra-Sekolah: Upaya Mengefektifkan Nilai-nilai Pendidikan Islam dalam Keluarga. Yogyakarta: Belukar, 2006.

Djamarah, Syaiful Bahri. Guru dan Anak Didik dalam Interaksi Edukatif: Suatu Pendekatan Teoretis Psikologis. Jakarta: Rineka Cipta, 2005.

Effendi, Zaenal. "Begini Cara Risma Cegah Kenakalan Remaja di Sekolah", detik news 15 Februari 2018 dalam https://news.detik.com/berita-jawa-timur/d-3868490, diakses 17 April 2018.

Farid, Achmad. "Model Bimbingan Konseling Islam Anwar Sutoyo dalam Mengatasi Kenakalan Remaja", Konseling Religi: Jurnal Bimbingan Konseling Islam, Vol. 6, No. 2, Desember 2015, h. 381-400.

Keputusan Menteri Agama Republik Indonesia Nomor 211 tahun 2011 tentang Pedoman Pengembangan Standar Nasional Pendidikan Agama Islam pada Sekolah

Keraf, A. Sonny. Etika Lingkungan Hidup. Jakarta: Penerbit Buku Kompas, 2010.

Maksudin. Pendidikan Nilai Komprehensif: Teori dan Praktik. Yogyakarta: UNY Press, 2009.

Muhaimin, Pengembangan Kurikulum Pendidikan Agama Islam di Sekolah, Madrasah, dan Perguruan Tinggi. Jakarta: Rajawali Pers, 2010.

Muhaimin, et. al. Paradigma Pendidikan Islam: Upaya Mengefektifkan Pendidikan Agama Islam di Sekolah, Madrasah, dan Perguruan Tinggi. Jakarta: PT. RajaGrafindo Persada, 2010. 
Penanaman Nilai-nilai... Oleh: Tasin Nurfalah

Peraturan Menteri Agama No. 16 tahun 2010 tentang Pengelolaan Pendidikan Agama pada Sekolah.

Shihab, Quraish. Wawasan Al-Quran: Tafsir Maudhu'i atas Pelbagai Persoalan Umat. Bandung: Penerbit Mizan, 1996.

Zuhairini. Filsafat Pendidikan Islam. Jakarta: PT. Bumi Aksara, 2008. 